\section{Abscisic Acid Application Affects Color and Acceptance of the New Hybrid 'BRS Melodia' Seedless Grape Grown in a Subtropical Region}

\author{
Renata Koyama, Ronan Carlos Colombo, Wellington Fernando Silva Borges, \\ João Pedro Silvestre, Ibrar Hussain, Muhammad Shahab, Saeed Ahmed, \\ and Sandra Helena Prudencio \\ Agricultural Research Center, Londrina State University, Celso Garcia Cid \\ Road, km 380, P.O. Box 10.011, 86057-970, Londrina, PR, Brazil
}

\section{Reginaldo Teodoro de Souza}

Embrapa Grape and Wine, P.O. Box 130, 95700-00 Bento Gonçalves, RS, Brazil

\author{
Sergio Ruffo Roberto ${ }^{1}$ \\ Agricultural Research Center, Londrina State University, Celso Garcia Cid \\ Road, km 380, P.O. Box 10.011, 86057-970, Londrina, PR, Brazil
}

Additional index words. growth regulator, $S$-ABA, visual-sensory analysis, Vitis vinifera

\begin{abstract}
The application of $S$-ABA enantiomer to clusters of poor pigmentation cultivars can improve grape color. The aim of this study was to assess whether $S$-ABA applied to clusters of the new hybrid 'BRS Melodia' seedless grape can improve its color characteristics and to evaluate the consumer acceptance. The following treatments were evaluated: Control; $S$-ABA at $200 \mathrm{mg} \cdot \mathrm{L}^{-1} 7$ days after veraison (DAV); $S$-ABA at 400 $\mathrm{mg} \cdot \mathrm{L}^{-1} 7 \mathrm{DAV} ; S$-ABA at $200 \mathrm{mg} \cdot \mathrm{L}^{-1} 7 \mathrm{DAV}+200 \mathrm{mg} \cdot \mathrm{L}^{-1} 21 \mathrm{DAV}$; and $S$-ABA at 400 $\mathrm{mg} \cdot \mathrm{L}^{-1} 7 \mathrm{DAV}+400 \mathrm{mg} \cdot \mathrm{L}^{-1} 21 \mathrm{DAV}$. To apply the treatments, clusters were sprayed using a backpack sprayer until runoff. The exogenous application of $S$-ABA significantly improves the color of berries of 'BRS Melodia' seedless grape, particularly at a concentration of $400 \mathrm{mg} \cdot \mathrm{L}^{-1}$ in two applications, at $7 \mathrm{DAV}$ and $21 \mathrm{DAV}$, resulting in clusters with greater consumer acceptance through visual-sensory analysis. Regardless of concentration or application timing, there was no change in the physicochemical characteristics of the berries or clusters, nor in the number of shoots per cane or clusters per shoot in the season after its application.
\end{abstract}

The global fruit trade has undergone important changes related to consumer habits, patterns, and income. Consumption has been increasingly directed toward the purchase of fresh food, which offers stronger assurance in terms of nutritional, health, and organoleptic qualities (Lazzarotto and Fioravanço 2012). In this context, to meet growing consumer market demand, especially the international consumer market for table grapes, the production of seedless fruits, which are considered of relatively high quality, is increasing every year (Colombo et al., 2011).

A unique difference of table grapes grown in some subtropical and tropical regions in the Southern Hemisphere is the twice-annual cropping system, what is possible because of technology developed for the cultivation of

\footnotetext{
Received for publication 10 Jan. 2019. Accepted for publication 26 Mar. 2019.

The authors thank the Coordination for the Improvement of Higher Education Personnel (CAPES) and the National Council for Scientific and Technological Development (CNPq), Brazil.

${ }^{1}$ Corresponding author. E-mail: sroberto@uel.br.
}

hybrid table grapes, all of them preceded by BRS (the Embrapa acronym for protected cultivars developed by the breeding program), such as 'BRS Morena', 'BRS Clara', and 'BRS Linda', were released in 2003, and 'BRS Vitoria' and 'BRS Isis' in 2012 and 2013, respectively (Colombo et al., 2011; Maia et al., 2014; Ritschel et al., 2013).

Among other hybrid seedless grapes developed by this breeding program is the 'BRS Melodia', which is an interspecific hybrid grape that, similar to the 'BRS Vitoria' and 'BRS Isis' grapes, results from the cross between CNPUV 681-29 [Arkansas $1976 \times$ CNPUV 147-3 ('Niagara' $x$ 'Venus')] $\times$ 'BRS Linda'. This new hybrid seedless grape is tolerant to downy mildew, the main grape disease in subtropical humid areas, requiring fewer fungicide applications. However, their slightly pinkish clusters show color deficiency when cultivated in warm subtropical regions, which may reduce the commercial value of grapes (Ritschel et al., 2019).

High temperatures at the beginning of grape ripening may decrease the levels of abscisic acid (ABA), and during this process may reduce the accumulation of anthocyanins and increase their degradation (Koshita et al., 2015), which can result in a lack of red, uniform color. Through sensory analysis, a preference for red grapes with darker color was observed, highlighting the superiority of 'Isabella' grape (dark purple-red), followed by 'Benitaka' (red), 'Italia' (yellowish green), and 'Festival' (green) (Mascarenhas et al., 2010).

ABA acts on important physiological processes during the grapevine cycle (Setha, 2012), and its levels are part of the signal that triggers fruit maturation, playing a role in regulating the ripening and senescence of nonclimacteric fruits (Yang and Feng, 2015). It plays an important regulatory role in grape development, which is marked by berry color change at the onset of ripening, increasing the level of phenolic compounds. Among them, anthocyanins are responsible for most of the red, pink, purple, and blue fruit colors (Rattanakon et al., 2016; Yang and Feng, 2015; Zhang et al., 2014).

Applications of (S)-cis-abscisic acid ( $S$-ABA), a natural ABA enantiomer, are effective at increasing endogenous ABA levels (Ferrara et al., 2013), accelerating the coloring process (Cantín et al., 2007) and increasing the uniformity of the color of grape clusters (Koyama et al., 2018; Roberto et al., 2012, 2013) without altering the physical characteristics of the berry ( $\mathrm{Li}$ and Dami, 2016). However, these results may vary according to the grape cultivar (Sandhu et al., 2011), application concentrations (Kretzschmar et al., 2016), application timing (Gu et al., 2011), and environmental conditions (Leao et al., 2014). So far, most of the $S$-ABA trials have been carried out for vinifera table grapes, and as 'BRS Melodia' is a new hybrid seedless cultivar, its response to multiple exogenous $S$-ABA application for berry color improvement is still not known, especially when it is grown under double-cropping system in 
subtropical areas. In addition, its effect on consumers' intention to purchase and on the grapevine regrowth in the following season after its application are still unknown.

Thus, the objective of this work was to evaluate the effect of various concentrations and application timings of $S$-ABA on the new hybrid 'BRS Melodia' seedless grape grown under a double-cropping system in a subtropical area, aiming to improve its color attributes and evaluate consumer preference in relation to grape appearance.

\section{Materials and Methods}

The study was conducted in a 4-year-old commercial vineyard of the new hybrid 'BRS Melodia' seedless grape (Vitis spp.), grafted onto 'IAC 766 Campinas' rootstock [Vitis riparia $\times($ Vitis rupestris $\times$ Vitis cordifolia) 106-8 Mgt] $\times$ Vitis caribaea, located in Marialva, Parana state, Brazil (lat. $23^{\circ} 29^{\prime} 52^{\prime \prime} 8 \mathrm{~S}$, long. $51^{\circ} 47^{\prime} 58^{\prime \prime} 0 \mathrm{~W}$ and elevation $570 \mathrm{~m}$ ) during two consecutive seasons (summer crop season 2013 and offseason crop 2014). According to Köppen's classification, the climate of the region is type Cfa (subtropical climate), with an average temperature in the coldest month below $18^{\circ} \mathrm{C}$ (mesothermic) and an average temperature in the hottest month above $22{ }^{\circ} \mathrm{C}$, with $1596 \mathrm{~mm}$ annual rainfall distributed through the year (Caviglione et al., 2000). The soil is classified as dystrophic red latosol (Bhering and Santos, 2008).

The vines were trained on overhead trellis and spaced $2.5 \times 2.5 \mathrm{~m}$ under $18 \%$ black mesh. Cane pruning was carried out in late winter in the summer season of 2013, leaving 4 to 6 buds per cane and in midsummer in the off-season of 2014, leaving 8 to 10 buds per cane, with 40 canes per vine in both seasons. Hydrogen cyanamide 3\% was then applied on the two apical buds to induce and standardize bud burst.

A randomized complete block design was used as a statistical model with five treatments and four replications, each plot consisting of one grapevine. Before the application of the treatments, 10 representative clusters were marked in each plot for physicochemical evaluation of the berries.

The effect of the $S$-ABA isomer, applied at different concentrations and timings, on grape clusters was evaluated. $S$-ABA, at an active ingredient concentration of $100 \mathrm{~g} \cdot \mathrm{L}^{-1}$, was supplied by Valent BioScienses Corporation (Libertyville, IL). The following treatments were tested: (1) control; (2) $S$-ABA $200 \mathrm{mg} \cdot \mathrm{L}^{-1}$ at $7 \mathrm{DAV}$; (3) $S$-ABA $400 \mathrm{mg} \cdot \mathrm{L}^{-1}$ $7 \mathrm{DAV}$; (4) $S$-ABA $200 \mathrm{mg} \cdot \mathrm{L}^{-1} 7 \mathrm{DAV}+200$ $\mathrm{mg} \cdot \mathrm{L}^{-1} 21 \mathrm{DAV}$; and (5) $S$-ABA $400 \mathrm{mg} \cdot \mathrm{L}^{-1}$ $7 \mathrm{DAV}+400 \mathrm{mg} \cdot \mathrm{L}^{-1} 21 \mathrm{DAV}$.

Veraison began $102 \mathrm{~d}$ after pruning in summer season 2013 and 85 d after pruning in off-season 2014 (Fig. 1). The onset of veraison was determined by analysis of the soluble solids (SS) content and visual evaluation of the color and consistency of the berries throughout the experimental area using random single samples $(n=5)$ of 30

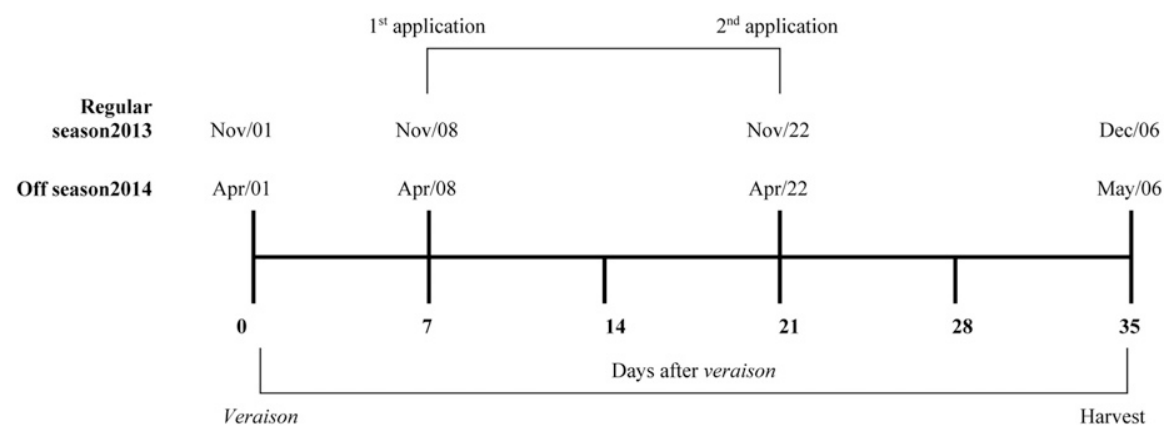

Fig. 1. Sample collection schedule for 'BRS Melodia' seedless grape treated with $S$-ABA during summer season 2013 and off-season 2014.

berries each. At this stage, the SS content of the grapes was on average $9{ }^{\circ}$ Brix, when some berries showed the beginning of color change, and $20 \%$ of the berries on $50 \%$ of the clusters had softened. At the first ABA application (7 DAV), the grapes on average measured $11{ }^{\circ}$ Brix, whereas a mean value of $13{ }^{\circ}$ Brix was observed at the second application (21 DAV).

The treatments were applied by spraying only the clusters in the morning, using a knapsack sprayer with hollow cone spray nozzles JA1, providing complete and uniform coverage, and using a spray volume of $800 \mathrm{~L} \cdot \mathrm{ha}^{-1}$. Break Thru nonionic surfactant $\left(0.3 \mathrm{~mL} \cdot \mathrm{L}^{-1}\right)$ was added to the spray solution of all treatments.

The crop management practices adopted for plant nutrition, weed control, and pest and disease management were those commonly used in the region. When berries reached 15 ${ }^{\circ}$ Brix the clusters of all treatments were harvested in the same day. In the summer season, the harvest was performed in early December, and in the off-season, the harvest was carried out in early May. From each plot, 30 berries were collected for physicochemical evaluation by removing one berry from the upper, middle, and lower portions of each marked cluster.

In both seasons, the following variables were evaluated: berry color attributes, berry mass and diameter, cluster mass and length, SS, titratable acidity (TA), SS/TA ratio, consumer acceptance of clusters, numbers of shoots per cane, and number of clusters per shoot in the following ABA-treated season.

For the evaluation of the color attributes, 10 berries were used per repetition (i.e., vine), using the Minolta CR-10 colorimeter, and the following variables of its equatorial portion were obtained: $L^{*}$ (lightness), $C^{*}$ (chroma), and $h^{\circ}$ (hue). Lightness values range from 0 (black) to 100 (white). Chroma indicates the saturation of the color, that is, the distance from gray (achromatic) to a pure color, and is calculated from the $a^{*}$ and $b^{*}$ values of the CIELab scale system. The scale does not have an arbitrary end, but the purity increases with magnitude. Hue refers to the color wheel and is measured in angles; green, yellow, and red correspond to $180^{\circ}, 90^{\circ}$, and $0^{\circ}$, respectively (Lancaster et al., 1997; Orak, 2007).
The residual color difference $(\Delta E)$ of the berries, used to calculate the color differences between the treatments and the control, was calculated using the following equation:

$$
\Delta E=\sqrt{\left(\Delta h^{\circ}\right)^{2}+\left(\Delta C^{*}\right)^{2}+\left(\Delta L^{*}\right)^{2}},
$$

where $\Delta \mathrm{h}^{\circ}$ is the hue angle difference, $\Delta C^{*}$ is the chroma difference, and $\Delta L^{*}$ is the lightness difference (Lucas et al., 2008).

The color magnitude of the clusters was visually evaluated by a sensory panel of 15 judges, assigning scores from 1 to 3 according to the following scale: $1=$ low, $2=$ medium, and $3=$ high, whereas the type of red color of the berries was visually evaluated by assigning scores from 1 to $3: 1=$ pale, $2=$ pink, and $3=$ red (Roberto et al., 2012).

The physical characteristics of the grapes were evaluated by determination of the mass $(\mathrm{g})$, diameter $(\mathrm{mm})$, and length $(\mathrm{mm})$ of 30 berries and the mass $(\mathrm{g})$ and length of clusters (cm) of 10 clusters per plot using a scale and digital calipers. For the SS, TA, and SS/TA variables, 30 berries collected per plot were used for the analyses. The SS content was determined by crushing the berries in a digital refractometer with automatic temperature compensation (Model DR301-95; Krüss Optronic, Germany), and the results were expressed in ${ }^{\circ}$ Brix. The TA was determined by titrating the grape juice with a standard solution of $0.1 \mathrm{~N} \mathrm{NaOH}$ in a semiautomatic titrator. The titration endpoint was a $\mathrm{pH}$ of 8.2 , and the results were expressed as a percentage of tartaric acid (Instituto Adolfo Lutz, 2008).

For the visual-sensory analysis of grapes acceptance by consumers regarding their appearance in the 2014 season, a completely randomized block design was adopted, and the analysis was performed by 100 untrained participants. The evaluations were carried out in individual booths with special daylight illumination in the Laboratory of Sensory Analysis. Samples containing 12 berries, removed from the upper, middle, and lower portions of four marked clusters of each plot, were placed in white plastic dishes, and each judge received, at the same time and in random order, the five samples from each treatment coded with a random three-digit numbers. The color and appearance attributes 
of each berry were evaluated using a 9-point hedonic scale anchored at its endpoints as follows: disliked very much (1) and liked very much (9), and a 7-point hedonic scale was used for purchase intention, anchored at its endpoints as follows: $1=$ would definitely not buy and $7=$ would definitely buy (Meilgaard et al., 1999).

To determine whether the applications of the plant growth regulator $S$-ABA had any effect on the regrowth in the following season after its application, the number of shoots per cane and the number of clusters per shoot were assessed by evaluating 10 canes per plot, considering that after pruning, only the two apical buds of the canes were treated with hydrogen cyanamide to stimulate bud burst. The evaluations were performed $20 \mathrm{~d}$ after flowering in the seasons after the applications (Camili et al., 2010).

The data were subjected to analysis of variance, and the means were compared by Tukey's test at a $5 \%$ probability.

\section{Results}

The treatments in which $S$-ABA was applied twice (7 DAV and $21 \mathrm{DAV}$ ) at 200 and $400 \mathrm{mg} \cdot \mathrm{L}^{-1}$ and once at $400 \mathrm{mg} \cdot \mathrm{L}^{-1}$ 7 DAV resulted in a lower $L^{*}$ compared with the control in both seasons, indicating that the grape berries had a darker color (Table 1). Lower $C^{*}$ values were observed in treatments with $S$-ABA application compared with control, except when $200 \mathrm{mg} \cdot \mathrm{L}^{-1} 7 \mathrm{DAV}$ was applied in the 2013 season, which resulted in berries with less saturated color toward gray, because $C^{*}$ was closer to zero.

The application of $S$-ABA resulted in a lower mean of $h^{\circ}$ compared with control, except when $200 \mathrm{mg} \cdot \mathrm{L}^{-1} 7 \mathrm{DAV}$ was applied in the 2013 season (Table 2), showing the development of the red color of the berries because a lower $h^{\circ}$ value corresponds to a redder berry (Lima et al., 2007). Regarding the residual color difference between the berries $(\Delta E)$ treated with $S$-ABA and the control (Table 2), when $\Delta E$ more closely approached zero, the red grape surfaces were more similar to the control (Lucas et al., 2008). When $400 \mathrm{mg} \cdot \mathrm{L}^{-1}$ was applied, $\Delta E$ increased regardless of the application timing.

Regarding the magnitude and type of red color of the berries, significant differences were observed among treatments (Fig. 2), particularly the nonuniformity of color within clusters (see Fig. 2A and B).

The highest means were observed when $400 \mathrm{mg} \cdot \mathrm{L}^{-1} S$-ABA was applied once or twice, resulting in clusters with a redder color (Table 3), and it was possible to observe the superiority of these treatments in the color of the clusters.

In the two seasons evaluated, there were no significant differences among treatments for the mass and diameter of the berries, mass and length of the clusters, SS content, TA, and SS/TA of 'BRS Melodia' seedless grape (Tables 4-6).

As for the visual-sensory analysis of the grapes, the most highly preferred berries by testers based on the color evaluation were
Table 1. Lightness $\left(L^{*}\right)$ and chroma $\left(C^{*}\right)$ of 'BRS Melodia' seedless grape subjected to different $S$-ABA treatments for the 2013 summer season and 2014 off-season crops.

\begin{tabular}{|c|c|c|c|c|}
\hline \multirow[b]{2}{*}{ Treatments (concn in $\mathrm{mg} \cdot \mathrm{L}^{-1}$ ) } & \multicolumn{2}{|c|}{$L^{*}$} & \multicolumn{2}{|c|}{$C^{*}$} \\
\hline & 2013 & 2014 & 2013 & 2014 \\
\hline Control & $34.2 \pm 1.1 \mathrm{a}^{\mathrm{z}}$ & $36.4 \pm 0.5 \mathrm{a}$ & $13.9 \pm 1.3 \mathrm{a}$ & $11.1 \pm 0.2 \mathrm{a}$ \\
\hline$S$-ABA 200 (7 DAV) & $32.0 \pm 0.6 \mathrm{ab}$ & $29.5 \pm 1.6 \mathrm{~b}$ & $11.5 \pm 0.5 \mathrm{ab}$ & $7.8 \pm 0.9 \mathrm{~b}$ \\
\hline$S$-ABA 400 (7 DAV) & $29.4 \pm 1.0 \mathrm{bc}$ & $26.3 \pm 0.7 \mathrm{c}$ & $9.8 \pm 1.6 \mathrm{bc}$ & $5.5 \pm 0.5 \mathrm{~cd}$ \\
\hline$S$-ABA $200(7 \mathrm{DAV})+200(21 \mathrm{DAV})$ & $29.7 \pm 0.8 b$ & $26.6 \pm 0.4 \mathrm{c}$ & $8.3 \pm 0.4 \mathrm{bc}$ & $6.4 \pm 0.9 \mathrm{bc}$ \\
\hline$S$-ABA $400(7 \mathrm{DAV})+400(21 \mathrm{DAV})$ & $26.9 \pm 1.0 \mathrm{c}$ & $25.4 \pm 0.4 \mathrm{c}$ & $6.5 \pm 1.4 \mathrm{c}$ & $3.6 \pm 0.5 \mathrm{~d}$ \\
\hline$F$ value & $20.2 *$ & $59.8 *$ & $14.3 *$ & $36.0 *$ \\
\hline $\mathrm{CV}(\%)$ & 4.0 & 3.6 & 15.1 & 13.5 \\
\hline
\end{tabular}

${ }_{\mathrm{z}}$ Means within columns followed by different letters differ significantly by Tukey's test $(P<0.05)$.

* Significant at $P<0.05$.

$\mathrm{DAV}=$ days after veraison

Table 2. Hue angle $\left(h^{\circ}\right)$ and residual color difference $(\Delta E)$ of 'BRS Melodia' seedless grape subjected to different $S$-ABA treatments for the 2013 summer season and 2014 off-season crops.

\begin{tabular}{|c|c|c|c|c|}
\hline \multirow[b]{2}{*}{ Treatments (concn in $\mathrm{mg} \cdot \mathrm{L}^{-1}$ ) } & \multicolumn{2}{|c|}{$h^{\circ}$} & \multicolumn{2}{|c|}{$\Delta E$} \\
\hline & 2013 & 2014 & 2013 & 2014 \\
\hline Control & $106.5 \pm 7.6 \mathrm{a}^{\mathrm{z}}$ & $96.8 \pm 5.2 \mathrm{a}$ & - & - \\
\hline$S$-ABA 200 (7 DAV) & $91.3 \pm 6.3 \mathrm{ab}$ & $46.0 \pm 5.4 b$ & $41.2 \pm 6.3 \mathrm{c}$ & $49.4 \pm 1.3 \mathrm{~b}$ \\
\hline$S$-ABA $400(7 \mathrm{DAV})$ & $78.5 \pm 8.3 \mathrm{bc}$ & $39.0 \pm 4.9 \mathrm{~b}$ & $63.7 \pm 8.3 \mathrm{ab}$ & $58.4 \pm 6.0 \mathrm{a}$ \\
\hline$S$-ABA $200(7 \mathrm{DAV})+200(21 \mathrm{DAV})$ & $69.0 \pm 7.6 \mathrm{c}$ & $39.4 \pm 4.8 b$ & $54.2 \pm 7.5 \mathrm{~b}$ & $51.4 \pm 2.2 \mathrm{ab}$ \\
\hline$S$-ABA $400(7 \mathrm{DAV})+400(21 \mathrm{DAV})$ & $47.7 \pm 4.9 \mathrm{~d}$ & $49.3 \pm 7.2 \mathrm{~b}$ & $85.3 \pm 5.0 \mathrm{a}$ & $59.0 \pm 6.9 \mathrm{a}$ \\
\hline$F$ value & $21.7 *$ & $21.5^{*}$ & $14.8^{*}$ & $17.2^{*}$ \\
\hline $\mathrm{CV}(\%)$ & 12.2 & 19.4 & 15.8 & 4.3 \\
\hline
\end{tabular}

${ }^{\mathrm{z}}$ Means within columns followed by different letters differ significantly by Tukey's test $(P<0.05)$.

* Significant at $P<0.05$.

$\mathrm{DAV}=$ days after veraison.
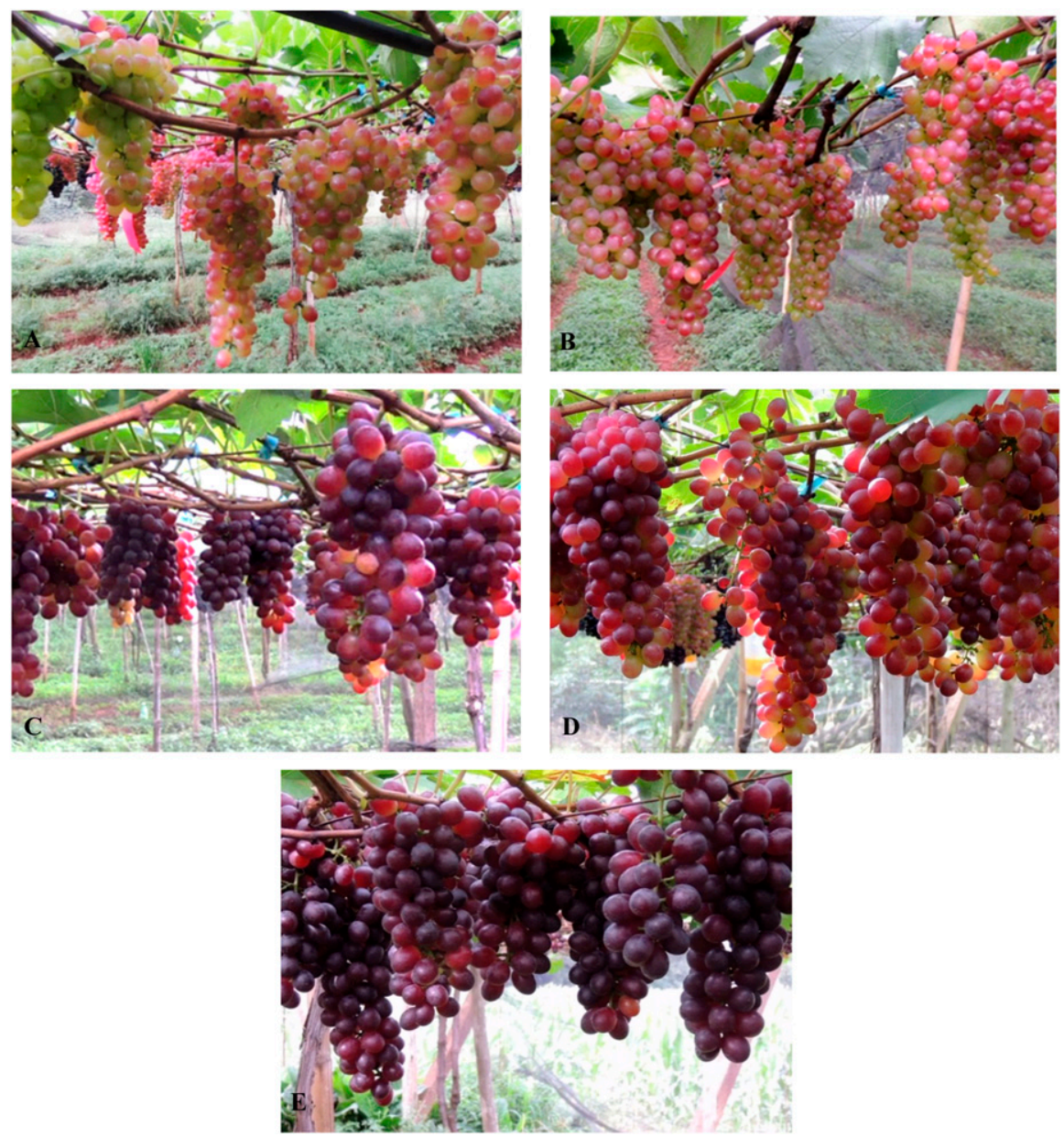

Fig. 2. Bunch characteristics of 'BRS Melodia' seedless grape at harvest. (A) Control; (B) S-ABA 200 $\mathrm{mg} \cdot \mathrm{L}^{-1} 7 \mathrm{~d}$ after veraison (DAV); (C) $S$-ABA $400 \mathrm{mg} \cdot \mathrm{L}^{-1} 7 \mathrm{DAV}$; (D) $S$-ABA $200 \mathrm{mg} \cdot \mathrm{L}^{-1} 7 \mathrm{DAV}+200$ $\mathrm{mg} \cdot \mathrm{L}^{-1} 21 \mathrm{DAV}$; and (E) $S$-ABA $400 \mathrm{mg} \cdot \mathrm{L}^{-1} 7 \mathrm{DAV}+400 \mathrm{mg} \cdot \mathrm{L}^{-1} 21 \mathrm{DAV}$. 
those that received two applications of 400 $\mathrm{mg} \cdot \mathrm{L}^{-1} S$-ABA and had a darker skin color (Table 7). The greater acceptance of the berries subjected to $S$-ABA application can be proven both by the higher scores assigned to the appearance of the berries treated with $400 \mathrm{mg} \cdot \mathrm{L}^{-1}$ (regardless of the season in

which $S$-ABA was applied) and by purchase intention.

Finally, no differences were observed among $S$-ABA-treated vines and the control for the number of shoots per cane and the number of clusters per shoots in the season after its application (Table 8).

Table 3. Magnitude and color type of 'BRS Melodia' seedless grape subjected to different $S$-ABA treatments during the 2013 summer season and 2014 off-season crops.

\begin{tabular}{lcccccc}
\hline & \multicolumn{2}{c}{ Cluster color magnitude } & & \multicolumn{2}{c}{ Cluster color type $^{\mathrm{y}}$} \\
\cline { 2 - 3 } \cline { 5 - 6 } Treatments (concn in mg. $\left.\mathrm{L}^{-1}\right)$ & 2013 & 2014 & & 2013 & 2014 \\
\hline Control & $1.0 \pm 0.0 \mathrm{~d}^{\mathrm{x}}$ & $1.0 \pm 0.0 \mathrm{~d}$ & & $1.0 \pm 0.0 \mathrm{~d}$ & $1.0 \pm 0.0 \mathrm{~d}$ \\
$S$-ABA $200(7 \mathrm{DAV})$ & $1.5 \pm 0.0 \mathrm{~cd}$ & $2.0 \pm 0.5 \mathrm{c}$ & & $1.5 \pm 0.5 \mathrm{~cd}$ & $2.0 \pm 0.0 \mathrm{c}$ \\
$S$-ABA $400(7 \mathrm{DAV})$ & $2.3 \pm 0.4 \mathrm{~b}$ & $2.8 \pm 0.4 \mathrm{ab}$ & & $2.3 \pm 0.4 \mathrm{~b}$ & $2.8 \pm 0.4 \mathrm{ab}$ \\
$S$-ABA 200 (7 DAV) $+200(21 \mathrm{DAV})$ & $2.0 \pm 0.4 \mathrm{bc}$ & $2.3 \pm 0.0 \mathrm{bc}$ & $2.0 \pm 0.0 \mathrm{bc}$ & $2.3 \pm 0.4 \mathrm{bc}$ \\
$S$-ABA 400 (7 DAV) $+400(21 \mathrm{DAV})$ & $3.0 \pm 0.0 \mathrm{a}$ & $3.0 \pm 0.0 \mathrm{a}$ & & $3.0 \pm 0.0 \mathrm{a}$ & $3.0 \pm 0.0 \mathrm{a}$ \\
$F$ value & $19.7^{*}$ & & $24.3 *$ & & $19.7^{*}$ & $24.3^{*}$ \\
CV $(\%)$ & 17.5 & 14.4 & & 17.5 & 14.4 \\
\hline
\end{tabular}

${ }^{\mathrm{z} C o l o r ~ m a g n i t u d e ~ c l a s s e s: ~(1) ~ l o w, ~(2) ~ m e d i u m, ~ a n d ~(3) ~ h i g h . ~}$

${ }^{\mathrm{y}}$ Color type classes: (1) pale, (2) pink, and (3) red.

${ }^{\mathrm{x}}$ Means within columns followed by different letters differ significantly by Tukey's test $(P<0.05)$.

Ns, *Nonsignificant or significant at $P<0.05$, respectively.

$\mathrm{DAV}=$ days after veraison. Sensory panel of 15 judges.

Table 4. Berry mass and diameter of 'BRS Melodia' seedless grapes subjected to different treatments of $S$-ABA during the 2013 summer season and 2014 off-season crops.

\begin{tabular}{lccccr}
\hline & \multicolumn{2}{c}{ Berry mass $(\mathrm{g})$} & & \multicolumn{2}{c}{ Berry diam $(\mathrm{mm})$} \\
\cline { 2 - 3 } Treatments (concn in $\left.\mathrm{mg} \cdot \mathrm{L}^{-1}\right)$ & 2013 & 2014 & & 2013 & 2014 \\
\hline Control & $4.3 \pm 0.3$ & $3.7 \pm 0.2$ & & $17.5 \pm 0.1$ & $16.3 \pm 0.1$ \\
$S$-ABA 200 (7 DAV) & $4.4 \pm 0.1$ & $3.8 \pm 0.2$ & & $18.2 \pm 0.3$ & $16.3 \pm 0.1$ \\
$S$-ABA 400 (7 DAV) & $4.4 \pm 0.2$ & $3.8 \pm 0.2$ & & $17.0 \pm 0.3$ & $16.1 \pm 0.4$ \\
$S$-ABA 200 (7 DAV) + 200 (21 DAV) & $4.4 \pm 0.1$ & $3.9 \pm 0.1$ & & $17.2 \pm 0.3$ & $16.3 \pm 0.2$ \\
$S$-ABA 400 (7 DAV) + 400 (21 DAV) & $4.8 \pm 0.2$ & $3.9 \pm 0.1$ & & $17.4 \pm 0.3$ & $16.1 \pm 0.9$ \\
$F$ value & $2.4^{\mathrm{Ns}}$ & $0.7^{\mathrm{Ns}}$ & & $1.1^{\mathrm{Ns}}$ & $0.1^{\mathrm{Ns}}$ \\
CV $(\%)$ & 6.5 & 5.7 & & 5.3 & 3.8 \\
\hline
\end{tabular}

Means within columns followed by different letters differ significantly by Tukey's test $(P<0.05)$.

$\mathrm{DAV}=$ days after veraison; NS = nonsignificant.

Table 5. Bunch mass and length of 'BRS Melodia' seedless grapes subjected to different treatments of $S$-ABA during the 2013 summer season and 2014 off-season crops.

\begin{tabular}{|c|c|c|c|c|}
\hline \multirow[b]{2}{*}{ Treatments (concn in $\mathrm{mg} \cdot \mathrm{L}^{-1}$ ) } & \multicolumn{2}{|c|}{ Cluster mass $(\mathrm{g})$} & \multicolumn{2}{|c|}{ Cluster length $(\mathrm{cm})$} \\
\hline & 2013 & 2014 & 2013 & 2014 \\
\hline Control & $573.8 \pm 3.1$ & $360.9 \pm 13.9$ & $20.4 \pm 0.6$ & $18.4 \pm 0.2$ \\
\hline$S$-ABA 200 (7 DAV) & $566.7 \pm 15.0$ & $399.9 \pm 17.9$ & $21.1 \pm 0.3$ & $17.6 \pm 0.6$ \\
\hline$S$-ABA 400 (7 DAV) & $563.4 \pm 26.9$ & $352.9 \pm 4.6$ & $19.7 \pm 0.7$ & $17.1 \pm 0.3$ \\
\hline$S$-ABA $200(7 \mathrm{DAV})+200(21 \mathrm{DAV})$ & $587.5 \pm 50.9$ & $351.4 \pm 24.1$ & $20.9 \pm 0.6$ & $17.4 \pm 0.7$ \\
\hline$S$-ABA $400(7 \mathrm{DAV})+400(21 \mathrm{DAV})$ & $599.0 \pm 16.8$ & $329.6 \pm 13.7$ & $19.3 \pm 0.9$ & $16.9 \pm 0.2$ \\
\hline$F$ value & $0.5^{\mathrm{Ns}}$ & $2.1^{\mathrm{NS}}$ & $3.2^{\mathrm{Ns}}$ & $1.2^{\mathrm{Ns}}$ \\
\hline CV $(\%)$ & 7.4 & 9.8 & 4.1 & 6.0 \\
\hline
\end{tabular}

Means within columns followed by different letters differ significantly by Tukey's test $(P<0.05)$.

$\mathrm{DAV}=$ days after veraison; NS $=$ nonsignificant.

\section{Discussion}

Application of ABA (in the form of $S$ ABA) increases the redness and affects the saturation of the new hybrid 'BRS Melodia' berries. Similar observations were made on 'Crimson Seedless' table grape, in which application of $S$-ABA $400 \mathrm{mg} \cdot \mathrm{L}^{-1}$ at 1 and 4 weeks after veraison reduced the berry color attributes $L^{*}, C^{*}$, and $h^{\circ}$ (Ferrara et al., 2015). However, late applications may have limited the effect because the physiological stage of the berry may not be more active to respond to the growth regulator (Ferrara et al., 2015). Other cultivars showed a positive effect of $S$-ABA application, as in 'Flame Seedless' table grapes, where 300 and $600 \mathrm{mg} \cdot \mathrm{L}^{-1}$ applications of the growth regulator at veraison resulted in improved color attributes of berries (Peppi and Fidelibus, 2008), and the same result was observed with 'Benitaka' and 'Rubi' table grapes grown in subtropical conditions (Roberto et al., 2012, 2013; Shahab et al., 2019).

Grapes with redder berry indicate higher phenolic compounds content, and the presence of these compounds shows benefits to human health with high antioxidant activity. Moreover, color is one of the most important factors in the consumer choice process, directly influencing the commercial quality of the fruit (Abe et al., 2007; Liang et al., 2009; Mattiuz et al., 2009).

The magnitude and $h^{\circ}$ of the red color is often linked to the quality of the grape since people associate certain flavors with specific colors, and thus the perception of flavor and aroma tend to increase as the color intensifies (Keller, 2015). The greater acceptance of the berries subjected to $S$-ABA application in this study are consistent with the results obtained in 'Sovereign Coronation' grapes treated with $S$-ABA, with an improvement in the attractiveness, color, and preference of the clusters when the visual-sensory analysis was assessed (Reynolds et al., 2016).

An earlier harvest due to $S$-ABA application and the speeding of the color development is an important result for table grape growers, with significant consequences for both reducing labor costs (through a lower number of multiple harvests in a season) and improving the color and attractiveness of the berry for consumers. Also, the grape production is expected to be more profitable due

Table 6. Soluble solids (SS), titratable acidity (TA), and SS/TA ratio of 'BRS melodia' seedless grapes subjected to different treatments of $S$-ABA during the 2013 summer season and 2014 off-season crops.

\begin{tabular}{|c|c|c|c|c|c|c|}
\hline \multirow[b]{2}{*}{ Treatments (concn in $\mathrm{mg} \cdot \mathrm{L}^{-1}$ ) } & \multicolumn{2}{|c|}{$\mathrm{SS}\left({ }^{\circ}\right.$ Brix $)$} & \multicolumn{2}{|c|}{ TA (\% of tartaric acid) } & \multicolumn{2}{|c|}{$\mathrm{SS} / \mathrm{TA}$} \\
\hline & 2013 & 2014 & 2013 & 2014 & 2013 & 2014 \\
\hline Control & $15.1 \pm 0.4$ & $15.4 \pm 0.3$ & $0.5 \pm 0.1$ & $0.6 \pm 0.0$ & $24.6 \pm 1.7$ & $25.9 \pm 1.0$ \\
\hline$S$-ABA $200(7 \mathrm{DAV})$ & $15.1 \pm 0.4$ & $15.4 \pm 0.5$ & $0.6 \pm 0.1$ & $0.6 \pm 0.0$ & $27.1 \pm 3.0$ & $26.9 \pm 1.5$ \\
\hline$S$-ABA $400(7 \mathrm{DAV})$ & $14.9 \pm 0.6$ & $15.4 \pm 0.3$ & $0.6 \pm 0.0$ & $0.6 \pm 0.0$ & $26.8 \pm 2.1$ & $24.4 \pm 1.0$ \\
\hline$S$-ABA $200(7 \mathrm{DAV})+200(21 \mathrm{DAV})$ & $15.1 \pm 0.4$ & $15.8 \pm 0.2$ & $0.6 \pm 0.0$ & $0.6 \pm 0.0$ & $25.2 \pm 1.1$ & $27.8 \pm 0.4$ \\
\hline$S$-ABA $400(7 \mathrm{DAV})+400(21 \mathrm{DAV})$ & $14.9 \pm 0.4$ & $15.0 \pm 0.3$ & $0.6 \pm 0.0$ & $0.6 \pm 0.0$ & $26.0 \pm 0.4$ & $26.7 \pm 1.5$ \\
\hline$F$ value & $0.2^{\mathrm{Ns}}$ & $1.5^{\mathrm{Ns}}$ & $0.3^{\mathrm{NS}}$ & $0.4^{\mathrm{NS}}$ & $0.6^{\mathrm{NS}}$ & $1.6^{\mathrm{Ns}}$ \\
\hline CV (\%) & 3.7 & 3.1 & 16.4 & 13.6 & 19.4 & 7.9 \\
\hline
\end{tabular}

Means within columns followed by different letters differ significantly by Tukey's test $(P<0.05)$.

Ns, "Nonsignificant or significant at $P<0.05$, respectively.

$\mathrm{DAV}=$ days after veraison 
Table 7. Hedonic scale for the visual-sensory evaluation of the appearance, color, and purchase intention of 'BRS Melodia' seedless grapes subjected to different $S$-ABA treatments during the 2014 off-season crop.

\begin{tabular}{lccc}
\hline & \multicolumn{3}{c}{ Visual-sensory evaluation $^{z}$} \\
\cline { 2 - 4 } Treatments (concn in mg. $\mathrm{L}^{-1}$ ) & Berry color & Berry appearance & Purchase intention \\
\hline Control & $6.1 \pm 1.8 \mathrm{~b}^{\mathrm{y}}$ & $6.3 \pm 1.7 \mathrm{~b}$ & $4.4 \pm 1.7 \mathrm{c}$ \\
$S$-ABA 200 (7 DAV) & $6.7 \pm 1.7 \mathrm{ab}$ & $6.7 \pm 1.5 \mathrm{ab}$ & $4.9 \pm 1.7 \mathrm{bc}$ \\
$S$-ABA 400 (7 DAV) & $6.8 \pm 1.2 \mathrm{ab}$ & $7.0 \pm 1.1 \mathrm{ab}$ & $5.3 \pm 1.4 \mathrm{ab}$ \\
$S$-ABA 200 (7 DAV) + 200 (21 DAV) & $6.8 \pm 1.5 \mathrm{ab}$ & $6.8 \pm 1.6 \mathrm{ab}$ & $5.1 \pm 1.5 \mathrm{ab}$ \\
$S$-ABA 400 (7 DAV) + 400 (21 DAV) & $7.3 \pm 1.6 \mathrm{a}$ & $7.2 \pm 1.4 \mathrm{a}$ & $5.6 \pm 1.5 \mathrm{a}$ \\
$F$ value & $5.4^{*}$ & $4.2^{*}$ & $6.7^{*}$ \\
CV $(\%)$ & 27.4 & 24.1 & 33.0 \\
\hline
\end{tabular}

${ }^{\mathrm{z}}$ Nine-point hedonic scale: dislike extremely (1) to like extremely (9) for color and berry appearance, and 7-point hedonic scale: would definitely not buy (1) to would definitely buy (7) for purchase intention. ${ }^{\mathrm{y}}$ Means within columns followed by different letters differ significantly by Tukey's test $(P<0.05)$.

Ns, *Nonsignificant or significant at $P<0.05$, respectively.

$\mathrm{DAV}=$ days after veraison.

Table 8. Number of shoots per cane and number of clusters per shoot of 'BRS Melodia' seedless grapes in the following 2013 and $2014 S$-ABA-treated seasons.

\begin{tabular}{|c|c|c|c|c|}
\hline \multirow[b]{2}{*}{$\begin{array}{l}\text { Treatments } \\
\left(\text { concn in } \mathrm{mg} \cdot \mathrm{L}^{-1}\right)\end{array}$} & \multicolumn{2}{|c|}{ Number of shoots per cane } & \multicolumn{2}{|c|}{ Number of clusters per shoot } \\
\hline & $\begin{array}{l}\text { Following } \\
2013 \text { season }\end{array}$ & $\begin{array}{c}\text { Following } \\
2014 \text { season }\end{array}$ & $\begin{array}{l}\text { Following } \\
2013 \text { season }\end{array}$ & $\begin{array}{l}\text { Following } \\
2014 \text { season }\end{array}$ \\
\hline Control & $1.5 \pm 0.1$ & $1.5 \pm 0.1$ & $2.2 \pm 0.3$ & $1.5 \pm 0.1$ \\
\hline$S$-ABA 200 (7 DAV) & $1.6 \pm 0.1$ & $1.5 \pm 0.1$ & $2.3 \pm 0.2$ & $1.6 \pm 0.0$ \\
\hline$S$-ABA 400 (7 DAV) & $1.5 \pm 0.2$ & $1.4 \pm 0.0$ & $1.9 \pm 0.6$ & $1.5 \pm 0.1$ \\
\hline $\begin{array}{l}S \text {-ABA } 200(7 \mathrm{DAV})+ \\
200(21 \mathrm{DAV})\end{array}$ & $1.5 \pm 0.1$ & $1.6 \pm 0.1$ & $2.0 \pm 0.2$ & $1.5 \pm 0.1$ \\
\hline $\begin{array}{l}S \text {-ABA } 400(7 \mathrm{DAV})+ \\
\quad 400(21 \mathrm{DAV})\end{array}$ & $1.6 \pm 0.1$ & $1.6 \pm 0.2$ & $2.0 \pm 0.3$ & $1.9 \pm 0.6$ \\
\hline$F$ value & $0.4^{\mathrm{NS}}$ & $2.2^{\mathrm{Ns}}$ & $0.7^{\mathrm{Ns}}$ & $2.0^{\mathrm{NS}}$ \\
\hline CV $(\%)$ & 9.3 & 8.5 & 21.5 & 10.5 \\
\hline
\end{tabular}

$\mathrm{DAV}=$ days after veraison; $\mathrm{NS}=$ nonsignificant.

to the color improvement because the consumers directly evaluate berry color, which is therefore a determinant of the market value of table grapes (Ferrara et al., 2015).

In addition to color attributes, the size and mass of grape berries can be influenced by the crop management practices and climatic conditions during the growth period (Jackson, 2008). In both evaluated seasons, no significant differences were observed among treatments, and the same was observed regarding the morphometric characteristics of 'Crimson Seedless' berries treated with 400 or $800 \mathrm{mg} \cdot \mathrm{L}^{-1}$ of $S$-ABA at the onset of ripening (Lurie et al., 2009). Similarly, in 'Benitaka' and 'Rubi' table grapes, there was no effect of the application of $S$-ABA on the mass or diameter of the berries or on the mass or length of the clusters (Roberto et al., 2012, 2013). These results were also observed in 'Pinot Gris' and 'Isabella' grapes, with no changes in the physical properties of berries or clusters (Koyama et al., 2014; Li and Dami, 2016), nor in the physicochemical characteristics of 'Monastrell' (Ruiz-García et al., 2013) and 'Chambourcin' berries (Zhang and Dami, 2012).

The results may also vary according to the grape cultivar and the environmental conditions during the ripening period. For 'Flame Seedless' table grapes, a higher berry mass and lower TA were achieved by applying $S$-ABA (Peppi and Fidelibus, 2008). In contrast, a reduction in the berry mass was observed in 'Cabernet Sauvignon' treated of the ABA (+)-cis, trans formulation directly to the 'Sangiovese' grapevine buds showed inconsistent effects, resulting in an ultimate delay of bud burst by only 1 day (Hellman et al., 2006).

Considering our findings, it can be concluded that the exogenous application of $S$-ABA significantly improves the color of berries of the new hybrid 'BRS Melodia' seedless grape, particularly at a concentration of $400 \mathrm{mg} \cdot \mathrm{L}^{-1}$ in two applications, at $7 \mathrm{DAV}$ and $21 \mathrm{DAV}$, resulting in clusters with greater consumer acceptance through visual-sensory analysis. Regardless of the concentration or application timing, there is no change in the physicochemical characteristics of the berries or clusters or in the number of shoots per cane or clusters per shoot in the season after application.

\section{Literature Cited}

Abe, L.T., R.V. Mota, F.M. Lajolo, and M.I Genovese. 2007. Compostos fenólicos e capacidade antioxidante de cultivares de uvas Vitis labrusca L. e Vitis vinifera L. Food Sci. Technol. 27:394-400

Ahmed, S., S.R. Roberto, M. Shahab, R.C. Colombo, J.P. Silvestre, R. Koyama, and R.T Souza. 2019. Proposal of double-cropping system for 'BRS Isis' seedless grape grown in subtropical area. Scientia Hort. 251:118-126.

Balint, G. and A.G. Reynolds. 2013. Impact of exogenous Abscisic acid on vine physiology and grape composition of Cabernet Sauvignon. Amer. J. Enol. Viticult. 64:74-87.

Bhering, S.B. and H.G. Santos. 2008. Mapa de solos do estado do Paraná: Legenda atualizada. IAPAR, Rio de Janeiro, Brazil).

with this plant growth regulator 1 week before veraison (Balint and Reynolds, 2013).

ABA is related to the induction of bud dormancy (Taiz and Zeiger, 2017), and the exogenous application in clusters may influence the regrowth in subsequent seasons; however, no differences were observed among the vines treated with $S$-ABA and the control in terms of the number of shoots per cane or the number of clusters per shoot evaluated in the following $S$-ABA-treated seasons. This result suggests that there is no negative effect of $S$-ABA application on the regrowth of 'BRS Melodia' grapevine grown under a double-cropping system in a subtropical area. Similarly, in a trial carried out with the 'Cabernet Sauvignon' grape, the number of shoots and clusters per vine evaluated in the following seasons were not influenced by the concentrations or application timings of $S$-ABA (Gu et al., 2011).

It has been determined that exogenous $S$-ABA applied directly to 'Cabernet Sauvignon' clusters is not transported to the other parts of the vine, nor is it absorbed in sufficient quantities to affect the stomatal activity or leaf temperature (Balint and Reynolds, 2013). In theory, if the exogenous application of $S$-ABA resulted in its translocation and accumulation in the buds, inhibition of its development could occur in the next growth cycle because the dormancy of the buds is controlled by the internal accumulation of ABA (Taiz and Zeiger, 2017). On the other hand, the exogenous application
Camili, E.C., J.D. Rodrigues, and E.O. Ono. 2010. Biorreguladores na brotação da videira 'Superior Seedless'. Biosci. J. 26:339-346.

Cantín, C.M., M.W. Fidelibus, and C.H. Crisosto. 2007. Application of abscisic acid (ABA) at veraison advanced red color development and maintained postharvest quality of 'Crimson Seedless' grapes. Postharvest Biol Technol. 46:237-241.

Caviglione, J.H., L.R.B. Kiihl, P.H. Caramori, and D. Oliveira. 2000. Cartas climáticas do Paraná. IAPAR, Londrina, Brazil.

Colombo, L.A., A.M.D. Assis, A.J. Sato, D.J. Tessmann, W. Genta, and S.R. Roberto. 2011. Produção fora de época da videira 'BRS Clara' sob cultivo protegido. Cienc. Rural 41:798808.

Ferrara, G., A. Mazzeo, A.M.S. Matarrese, C. Pacucci, A. Pacifico, G. Gambacorta, M. Faccia, A. Trani, V. Gallo, I. Cafagna, and P. Mastrorilli. 2013. Application of abscisic acid ( $S$-ABA) to 'Crimson Seedless' grape berries in a Mediterranean climate: effects on color, chemical characteristics, metabolic profile, and $S$-ABA concentration. J. Plant Growth Regul. 32:491505 .

Ferrara, G., A. Mazzeo, A.M.S. Matarrese, C. Pacucci, R. Punzi, M. Faccia, A. Trani, and G. Gambacorta. 2015. Application of abscisic acid ( $S$-ABA) and sucrose to improve colour, anthocyanin content and antioxidant activity of cv. Crimson Seedless grape berries. Austral. J. Grape Wine Res. 21:18-29.

Gu, S., S. Jacobs, and G. Du. 2011. Efficacy, rate and timing of applications of abscisic acid to enhance fruit anthocyanin contents in 'Cabernet Sauvignon' grapes. J. Hort. Sci. Biotechnol. $86: 505-510$. 
Hellman, E., S. Shelby, and C. Lowery. 2006. Exogenously applied abscisic acid did not consistently delay budburst of acclimating grapevines. J. Amer. Pomol. Soc. 60:178-186.

Instituto Adolfo Lutz. 2008. Normas analíticas do Instituto Adolfo Lutz: Métodos químicos e físicos para análise dos alimentos. 3 ed. Instituto Adolfo Lutz, São Paulo, Brazil.

Jackson, R.S. 2008. Wine science: Principles and applications. 3rd ed. Elsevier, Amsterdam, The Netherlands.

Keller, M. 2015. The science of grapevines: Anatomy and physiology. 2nd ed. Elsevier: Amsterdam, The Netherlands.

Kishino, A.Y., C.J. Marur, and S.R. Roberto. 2019. Características da planta, p. 155-249. In: A.Y. Kishino, S.L.C. Carvalho, and S.R. Roberto (eds.). Viticultura tropical: O sistema de produção de uvas de mesa no Paraná.

Koshita, Y., N. Mitani, A. Azuma, and H. Yakushiji. 2015. Effect of short-term temperature treatment to bunches on anthocyanin and abscisic acid content in the peel of 'Aki Queen' grape. Vitis J. Grapevine Res 54:169-173.

Kretzschmar, A.A., S. Lerin, A.F. Fagherazzi, A.E. Mario, F.E.A. Bastos, R. Allebrandt, and L. Rufato. 2016. Application of abscisic acid increases the colour of 'Rubi' grape berries in Southern Brazil. Acta Hort. 1115:231-236.

Koyama, R., A.M. Assis, L.Y. Yamamoto, W.F. Borges, R. Sá Borges, S.H. Prudêncio, and S.R. Roberto. 2014. Exogenous abscisic acid increases the anthocyanin concentration of berry and juice from 'Isabel' grapes (Vitis labrusca L.). HortScience 49:460-464.

Koyama, R., S.R. Roberto, R.T. Souza, W.F.S. Borges, M. Anderson, A.L. Waterhouse, D. Cantu, M.W. Fidelibus, and B. Blanco-Ulate. 2018. Exogenous abscisic acid promotes anthocyanin biosynthesis and increased expression of flavonoid synthesis genes in Vitis vinifera $\times$ Vitis labrusca table grapes in a subtropical region. Front. Plant Sci. 9:323.

Lancaster, J.E., C.E. Lister, P.F.Y. Reay, and C.M. Triggs. 1997. Influence of pigment composition on skin color in a wide range of fruits and vegetables. J. Amer. Soc. Hort. Sci. 122:594598.

Lazzarotto, J.J. and J.C. Fioravanço. 2012. Comércio Exterior Mundial e Brasileiro de Uva de Mesa: Analise de Indicadores de Competitividade, Tendências e Sazonalidades. Embrapa Uva e vinho, Bento Gonçalves.

Leao, P.C.S., M.A.C. Lima, J.P.D. Costa, and D.C.G. Trindade. 2014. Abscisic acid and ethephon for improving red color and quality of 'Crimson Seedless' grapes grown in a tropical region. Amer. J. Enol. Viticult. 66:37-45.

Li, S. and I.E. Dami. 2016. Responses of Vitis vinifera 'Pinot Gris' grapevines to exogenous abscisic acid (ABA): I. Yield, fruit quality, dormancy, and freezing tolerance. J. Plant Growth Regul. 35:245-255.

Liang, Z., C. Yang, J. Yang, B. Wu, L. Wang, J. Cheng, and S. Li. 2009. Inheritance of anthocyanins in berries of Vitis vinifera grapes. Euphytica 167:113-125.

Lima, V.L.A.G., E.A. Melo, and N.B. Guerra. 2007. Correlação entre o Teor de Antocianinas e Caracterização Cromática de Polpas de Diferentes Genótipos de Aceroleira. Braz. J. Food. Technol. 10:51-55.

Lucas, M., P.F.P.T. Jeremias, J. Andreaus, O. Barcellos, D. Química, U.R. Blumenau, R.B. Antônio, and P. Peralta-Zamora. 2008. Reutilização de efluente de tingimentos de fibras acrílicas pós-tratamento fotoeletroquímico. Quim. Nova 31:1362-1366.

Lurie, S., R. Ovadia, A. Nissim-Levi, M. OrenShamir, T. Kaplunov, Y. Zutahy, H. Weksler, and A. Lichter. 2009. Abscisic acid improves colour development in 'Crimson Seedless' grapes in the vineyard and on detached berries. J. Hort. Sci. Biotechnol. 84:639-644.

Maia, J.D.G., P. Ritschel, U.A. Camargo, R.T. De Souza, T.V. Martins Fajardo, R.L. Naves, and C.L. Girardi. 2014. 'BRS Vitória'-a novel seedless table grape cultivar exhibiting special flavor and tolerance to downy mildew (Pasmopara viticola). Crop Breed. Appl. Biotechnol. 14:204-206.

Mascarenhas, R.D.J., S.D.M. Silva, J.D. Lopes, and M.A.C. Lima. 2010. Avaliação sensorial de uvas de mesa produzidas no Vale do São Francisco e comercializadas em João Pessoa-PB. Rev. Bras. Frutic. 32:993-1000.

Mattiuz, B., A.C.A. Miguel, V.C. Galati, and J.C. Nachtigal. 2009. Effect of stored temperature in minimally processed seedless table grapes. Rev. Bras. Frutic. 31:44-52.

Meilgaard, M., G.V. Civille, and B.T. Carr. 1999 Sensory evaluation techniques. 3rd ed. CRC Press, Boca Raton, FL.

Nachtigal, J.C. 2005. Uvas sem sementes. Rev. Bras. Frutic. 27:1-193.

Orak, H.H. 2007. Total antioxidant activities, phenolics, anthocyanins, polyphenoloxidase activities of selected red grape cultivars and their correlations. Scientia Hort. 111:235241.

Peppi, M.C. and M.W. Fidelibus. 2008. Effects of forchlorfenuron and abscisic acid on the quality of 'Flame Seedless' grapes. HortScience 43: 173-176.

Rattanakon, S., R. Ghan, G.A. Gambetta, L.G. Deluc, K.A. Schlauch, and G.R. Cramer. 2016. Abscisic acid transcriptomic signaling varies with grapevine organ. BMC Plant Biol. 16:72.

Reynolds, A., N. Robbins, H.S. Lee, and E. Kotsaki. 2016. Impacts and interactions of abscisic acid and gibberellic acid on 'Sovereign Coronation' and 'Skookum Seedless' table grapes. Amer. J. Enol. Viticult. 67:327338 .

Ritschel, P., J.D.G. Maia, U.A. Camargo, R.T. Souza, T.V.M. Fajardo, R.L. Naves, and C.L. Girardi. 2013. 'BRS Isis' Nova Cultivar de Uva de Mesa Vermelha, sem Sementes e Tolerante ao Míldio. Comunicado 143 Técnico.

Ritschel, P.S., J.D.G. Maia, U.A. Camargo, R.T. Souza, T.V.M. Fajardo, R.L. Naves, and C.L. Girardi. 2019. BRS Melodia. 1 Mar. 2019. $<$ https:/www.embrapa.br/busca-de-imagens/-/ midia/4570005/uva-brs-melodia $>$.

Roberto, S.R., A.M. De Assis, L.Y. Yamamoto, L.C.V. Miotto, A.J. Sato, R. Koyama, and W. Genta. 2012. Application timing and concentration of abscisic acid improve color of 'Benitaka' table grape. Scientia Hort. 142: 44-48.

Roberto, S.R., A.M. Assis, L.Y. Yamamoto, L.C.V Miotto, R. Koyama, A.J. Sato, and R.D.S. Borges. 2013. Ethephon use and application timing of abscisic acid for improving color of 'Rubi' table grape. Pesqui. Agropecu. Bras. 48:797-800.

Ruiz-García, Y., R. Gil-Muñoz, J.M. López-Roca, A. Martínez-Cutillas, I. Romero-Cascales, and E. Gómez-Plaza. 2013. Increasing the phenolic compound content of grapes by preharvest application of abcisic acid and a combination of methyl jasmonate and benzothiadiazole. J. Agr. Food Chem. 61:3978-3983.

Sandhu, A.K., D.J. Gray, J. Lu, and L. Gu. 2011. Effects of exogenous abscisic acid on antioxidant capacities, anthocyanins, and flavonol contents of muscadine grape (Vitis rotundifolia) skins. Food Chem. 126:982-988.

Shahab, M., S.R. Roberto, S. Ahmed, R.C. Colombo, J.P. Silvestre, R. Koyama, and R.T. Souza. 2019. Anthocyanin accumulation and color development of 'Benitaka' table grape subjected to exogenous abscisic acid application at different timings of ripening. Agronomy 9:e164-176.

Setha, S. 2012. Roles of abscisic acid in fruit ripening. Walailak J. Sci. Technol. 9:297-308.

Taiz, L. and E. Zeiger. 2017. Fisiologia vegetal. Artmed, Porto Alegre, Brazil.

Yang, F.W. and X.Q. Feng. 2015. Abscisic acid biosynthesis and catabolism and their regulation roles in fruit ripening. Phyton 84:444453.

Zhang, Y. and I. Dami. 2012. Improving freezing tolerance of 'Chambourcin' grapevines with exogenous abscisic acid. HortScience 47:1750 1757.

Zhang, Y., E. Butelli, and C. Martin. 2014. Engineering anthocyanin biosynthesis in plants. Curr. Opin. Plant Biol. 19:81-90. 